Note

\title{
Which factors play a role in the development of honours students to become professional leaders?
}

\author{
Arie Kool ${ }^{1}$
}

1. Hanze University of Applied Sciences Groningen, the Netherlands, a.kool@pl.hanze.nl

Received: 6 October 2017; Accepted: 23 October 2017; Published: 28 October 2017

Keywords: Professional leadership; honours students; personal development

\section{Introduction}

The world is facing fundamental issues that call for new insights and solutions (Scharmer \& Kaufman, 2013). These issues make that education is no (only) longer sufficient when educating people to find their way in the existing system, but also shows the need to invest in people who are interested in and want to think about new ways: professional leaders. A professional leader manifests leadership based on expertise and knowledge of the own profession (Plas \& Crijns, 2010). Leaders are the kind of people who love a challenge, who discover that old ways no longer work and who do not become insecure of the strange, uncertain and challenging (Bain, 2012).

The properties of professional leaders also become apparent in research on distinguishing features of honours students: they have higher intrinsic motivation (Kazemier, Offringa, Eggens, \& Wolfensberger, 2014; Wolfensberger \& Offringa, 2012), possess more cultural empathy and open mindedness (Kool \& Wolfensberger, 2014), are more extroverted and conscientious (Pullen, Griffioen, Schoonenboom, De Koning \& Beishuizen, 2014) and proactive (Banis, 2014). In honours education there is more space for students to make their own choices in their education.

The current research was part of a course that was offered for teachers involved in honours education at Hanze University of Applied Sciences in Groningen, the Netherlands ('A Teacher's Road to Excellence'). The challenge was to explore aspects of honours teaching and ways to develop honours teaching. In honours teaching an important role is being a coach. My aim was to find out more about the question how an honours coach could support the realisation of an important aim of this kind of education: the personal development of students to become future leaders in their field of work. In education it is still fairly unknown where coaching should focus on when it comes to the development of professional leadership qualities. Therefore, I wanted to explore the factors that contribute to becoming a professional leader. 


\section{Methods}

This qualitative research is built on open interviews with honours students $(n=10)$ at Hanze University of Applied Sciences, that were nominated by a teacher because they seemed to show obvious professional leadership. The assumption was that the personal stories of these students could uncover factors that formed them to become who they are today. During the interview relevant experiences such as: youth, school career, important events or people, results in school, sources of inspiration, important events, values and goals, successes and setbacks were explored. All interviews were recorded and transcribed. On bases of open coding the interviews were analyzed to find patterns in the personal stories of the students.

\section{Results}

The results showed remarkable resemblances in the stories of the respondents. The age of all participants in the research at the start of their study at a university of applied sciences (hbo in Dutch) is a number of years higher than average students. Most students went through "deviant" school careers, for example: a start in the pre-vocational secondary education and via a detour to higher education, a discontinuous high school career, or through pre-university education (vwo in Dutch) and research university to a university of applied sciences (hbo). Most important for the aim of this research: each respondent mentioned decisive personal events, experiences or persons which led to a conscious choice, waking up of certain motivators or the realization of own capabilities and qualities. Examples include:

- One respondent developed from a confrontation with severe school bullying through the discovery of being autistic to a transformation from a weakness to a strength (raising awareness for autism).

- Being raised in foster families and thereby continuous confrontation with new experiences led to learning to use the ability to deal with new experiences in a constructive way.

- A negative experience of having to go abroad on internship with poor language skills and an accident that forced complete reorientation led to a new start where learning from new situations became a challenge.

- A personal encounter with god gave the impulse to strive for social justice, especially in working with refugees.

- Being raised in a patchwork family created the wish to connect and deal with different people, cultures and environments.

- The experience of being a good student in high school with paternal pressure that was followed by a period of poorer achievements due to contact with "bad friends" led to discovering the intrinsic motivation to learn and develop: the discovery of own qualities by faith in and trust of teachers.

- Counseling on university transformed a negative start with school bullying and calculation problems into the discovery of room for personal choice.

- The early loss of father led to low self-esteem, but through an internship abroad and an intensive love affair the respondent regained self-confidence.

- The stimulus for learning came from a geography teacher who opened the world and the wish to explore. 


\section{Conclusion}

The development of each respondent is strongly influenced by specific events, experiences or people. From the personal story of each of the respondents it seems clear that the positive development speeds up when someone becomes aware of his/her personal motivators and found a way/ ways to connect to them.

\section{Discussion}

The results of this small sample seem to show that personal motives are related to personal strengths. Since the research is based on a very small and selective sample conclusions are speculative. As a result for teaching practice it points in the direction of the necessity of gaining insight in the personal story of a student to be able to support and encourage students in the development of professional leadership. This insight could be a starting point to help the student to recognize personal motives and strengths. This seems to be in support of a method like the strengths approach of Buckingham and Clifton (2016). According to this approach, people are more successful if they reinforce and exploit their strengths and put no unnecessary effort in improving their weaknesses. On this basis, a student may be encouraged to explore situations and contexts to effectively use the strengths and to find ways to minimize the damage of weaknesses.

\section{Acknowledgments}

This note was one of the outcomes of my participation in 'A Teacher's Road to Excellence', a course at Hanze University of Applied Sciences in Groningen, the Netherlands. As a teacher in honours programs I was given room to explore and develop teaching qualities which I found inspiring and enriching.

\section{References}

Bain, K. (2012). What the Best College Students Do. Cambridge, Massachusetts: Belknap Press.

Banis, J. (2014). Wat is er 'excellent' aan excellente studenten? Een nadere oriëntatie op criteria voor selectie en onderwijs gericht op excellente studenten. Symposium contribution during conference Onderwijs Research Dagen, Groningen, Netherlands, 11-13 June.

Buckingham, M. \& Clifton, D. O. (2016). Ontdek je sterke punten. Houten/Antwerpen: Spectrum.

Kazemier, E., Offringa, J., Eggens, L., \& Wolfensberger, M. (2014). Motivatie, leerstrategieën en voorkeur voor doceerbenadering van honoursstudenten in het hbo. Tijdschrift voor Hoger Onderwijs 4(1), 106-124.

Kool, A., \& Wolfensberger, M. (2014). Identificatie van excellente studenten. Tijdschrift voor Hoger Onderwijs 4(1), 80-93.

Plas, M. \& Crijns, M. (2010). Vakinhoudelijk leiderschap en de LPI. Nederlands Tijdschrift voor Evidence Based Practice 8(3), 20-22. 
Pullen, A. G., Griffioen, D. M. E., Schoonenboom, J., De Koning, B. \& Beishuizen, J. (2014). Wat is er 'excellent' aan excellente studenten? Een nadere oriëntatie op criteria voor selectie en onderwijs gericht op excellente studenten. Symposium contribution during conference Onderwijs Research Dagen, Groningen, Netherlands, 11-13 June.

Scharmer, O. \& Kaufman, K. (2013). Leading from the Emerging Future: From Ego-System to Eco-System. San Francisco, CA: Berrett-Koehler Publishers.

Wolfensberger, M. \& Offringa, J. (2012). Qualities that Student Look For in Faculty and courses, Revisited. Journal of the National Collegiate Honors Council, 2012 (3), 171-182. 